\title{
The impact of US sugar prices on the financial performance of US sugar-using firms
}

\author{
Carlos J. O. Trejo-Pech ${ }^{1 *}$ D, Karen L. DeLong ${ }^{1}$, Dayton M. Lambert ${ }^{2}$ and Vasileios Siokos ${ }^{1}$
}

\author{
* Correspondence: ctrejope@utk. \\ edu \\ ${ }^{1}$ Department of Agricultural \& \\ Resource Economics, University of \\ Tennessee, Knoxville, TN 37919, USA \\ Full list of author information is \\ available at the end of the article
}

\begin{abstract}
The effect of the United States (US) sugar program on sugar-using firm profitability from 2000 to 2017 is examined using firm financial data and the relative US-to-world sugar price ratio. Return on assets and market-to-book ratio proxy for firm financial performance. The regression results provide statistical evidence that as the US sugar price increases relative to the world sugar price, sugar-using firm financial performance improves. This is likely a result of sugar-using firms passing higher sugar costs on to consumers. An ex post analysis indicates that the statistical tests have adequate power. Findings provide guidelines for future analyses investigating the relationship between the US sugar program and sugar-using firm financial performance.
\end{abstract}

Keywords: Agribusiness finance, Sugar-using firms, US sugar program, Power of test JEL classification: G32, M2

\section{Introduction}

The US sugar program protects domestic sugar producers from world sugar prices because the world sugar market consists of heavily subsidized sugar from countries such as India and Brazil (Elobeid and Beghin 2006; Hodari 2018; Hudson 2019; USDA FAS 2019). The world sugar market carries the moniker of being the most distorted commodity market because nearly all sugar-exporting countries subsidize their sugar industries (Elobeid and Beghin 2006; Hodari 2018; Hudson 2019). Hudson (2019) outlines the various sugar subsidies used by sugar-exporting countries, which range from domestic price supports and input subsidies to ethanol mandates where sugar is the primary ethanol production feedstock. For example, Brazil is the largest world exporter of sugar. Chatenay (2013) estimated the value to the Brazilian cane industry from ethanol subsidies and other programs to be $\$ 2.5$ billion per year. Due to the mechanics of the US sugar program, and the fact that the world sugar market consists of mostly subsidized sugar, US raw and refined wholesale prices for sugar are typically higher than world raw and wholesale sugar prices. For instance, from 2000 to 2017, US raw sugar prices have been, on

(c) The Author(s). 2020 Open Access This article is licensed under a Creative Commons Attribution 4.0 International License, which permits use, sharing, adaptation, distribution and reproduction in any medium or format, as long as you give appropriate credit to the original author(s) and the source, provide a link to the Creative Commons licence, and indicate if changes were made. The images or other third party material in this article are included in the article's Creative Commons licence, unless indicated otherwise in a credit line to the material. If material is not included in the article's Creative Commons licence and your intended use is not permitted by statutory regulation or exceeds the permitted use, you will need to obtain permission directly from the copyright holder. To view a copy of this licence, visit http://creativecommons.org/licenses/by/4.0/. 
average, 10 cents per pound higher than world sugar prices (USDA ERS 2018). Critics argue that the US sugar program sustains a relatively small number of jobs in the sugar industry, while causing economic losses to sugar-using industries because US raw and wholesale prices are artificially higher than raw and wholesale world prices (Sweetener Users Association 2018).

This paper regresses indicators of firm performance on the US-to-world sugar price ratio to examine the effect of the US sugar program on the financial performance of publicly traded food manufacturers who use sugar as a primary input. We use a standard financial accounting model and include the US-to-world sugar price ratio as an explanatory variable. Our hypothesis is that as the US price of sugar increases relative to the world price of sugar, this change will negatively affect the financial performance of US sugar-using businesses as US sugar program critics contend (e.g., Sweetener Users Association 2018). Therefore, the null hypothesis we test is that the US-to-world sugar price ratio does not affect sugar-using firm financial performance. Industry analysts commonly emphasize the importance of sugar price variation on sugar-containing products manufacturers' profitability (Madigan 2017; Sanders IV 2018a; Sanders IV 2018b; Stivaros 2017c). It is expected that significant increases in input prices negatively affect firm profits ceteris paribus, but the magnitude of the effect of a higher domestic sugar price relative to the world price on sugar-using firm profitability remains unstudied. In the absence of previous research on this relationship, effect sizes that correspond with a powerful and economically significant test are uncertain. Type II error rates of the hypotheses tested are determined ex post. Results of the ex post power analysis provide upper and lower effect sizes that correspond with a powerful test, given the data and models. The effect size ranges we report could support policymakers and others concerned about the effects of the US sugar program on sugar-using firm performance in analyses designed to detect the distortionary effects of policies on firm financial performance.

\section{Literature review}

In 2008, Mexico became the leading exporter of sugar into the US when NAFTA was fully implemented for sugar. By 2013, Mexico accounted for nearly $70 \%$ of US sugar imports (Schmitz and Lewis 2015). Previous research forecasted the ex ante welfare implications of NAFTA (Abler et al. 2008; Kennedy and Petrolia 2000; Kennedy and Schmitz 2009; Knutson et al. 2010), as well as the ex post impact of NAFTA on US sugar markets (Schmitz and Lewis 2015). Schmitz and Lewis (2015) found that NAFTA cost US sugar producers $\$ 474$ million to $\$ 1.3$ billion annually. Research also examined the welfare impacts related to antidumping and countervailing investigations against Mexican exports of sugar into the US (Schmitz 2018; Schmitz and Lewis 2015; Zahniser et al. 2016). With respect to the Mexican countervailing investigation launched by the US International Trade Commission and the US Department of Commerce, Lewis and Schmitz (2015) found that if the Mexican government was removed from Mexican sugar production, US sugar producers would have gained $\$ 525$ to $\$ 1.6$ billion annually over the average of fiscal years 2012 and 2013. Schmitz (2018) found that if the 
2014 suspension agreement between the US and Mexico, which set a $\$ 22.25 / \mathrm{cwt}$ import price floor on US sugar imports from Mexico, were in effect from 2008 through 2014, US sugar producers would have gained \$138 million annually.

Previous research also examined the impact of trade liberalization of the world sugar market (Elobeid and Beghin 2006) as well as the estimated cost of the US sugar program to US consumers (Beghin and Elobeid 2015; Beghin et al. 2001). Beghin and Elobeid (2015) found that removal of the US sugar program would increase consumer surplus from $\$ 2.9$ to $\$ 3.5$ billion annually and generate approximately 20,000 jobs in food manufacturing industries. The same authors concluded that imports of products containing sugar would decline, whereas sugar imports would increase. Triantis (2016) investigated this assumption by examining the cost of the US sugar program to US sugar-using businesses in terms of jobs and financial performance. Triantis analyzed a sample of the nine largest US sugar-using manufacturers. Triantis concluded that the financial health of sugar-using businesses was stronger than in other comparable manufacturing industries. This study builds on Triantis's (2016) analysis. We use financial accounting and stock price data to test the hypothesis that US sugar prices affect the profits of US sugar-using businesses.

Research on agribusiness firm profitability investigates why firm accounting profits deviate from the norm, which is the competitive profit rate of return (Chaddad and Mondelli 2013; Gschwandtner and Hirsch 2018; Hirsch et al. 2014; Schumacher and Boland 2005). These studies conclude that profits deviating from the norm are persistent; where profit persistence is defined as a portion of firm profit return in 1 year remaining in the next year (Schumacher and Boland 2005). The resource-based view (RBV) theory explains profit persistence by positing that firms have unique and rare resources and capabilities that are difficult to imitate. Rumelt (1991) first showed that profits in manufacturing business are due to firm-specific resources rather than to industry membership, or equivalently, that firm profits within industries differ from one another a great deal more than industries profits differ from one another. Chaddad and Mondelli (2013), Hirsch et al. (2014), and Gschwandtner and Hirsch (2018) find that firm effects outweigh industry effects for profitability in the food sector.

\section{Data}

We examine the financial performance of 26 publicly traded sugar-using firms whose primary sugar purchases were made in the USA. Financial data from 2000 through 2017 was assembled from the COMPUSTAT North America database (COMPUSTAT) and the Center for Research in Security Prices (CRSP). COMPUSTAT and CRSP databases are widely used in finance and are commonly used in agribusiness research (Katchova and Enlow 2013; Schumacher and Boland 2005; Trejo-Pech et al. 2016).

We extracted information tracking 199 food and/or beverage manufacturers from the combined CRSP/COMPUSTAT database associate with the food and beverage manufacturing sector. We used the 2017 version of the North American Industry Classification System (NAICS) to categorize the firms in the database. The list of industries examined included sugar-containing food manufacturing 
industries according to Triantis (2016), plus beverage manufacturers according to NAICS definitions. ${ }^{1}$ Not all firms in these industries necessarily consume substantial amounts of sugar as a primary input. Sugar-using firms were identified according to industry market research reports by IBISWorld (Madigan 2017; Sanders IV 2018a; Sanders IV 2018b; Stivaros 2017a, 2017b, 2017c, 2017d), Triantis (2016), and the authors' inspection of firms' annual reports. We refined the list of firms by screening annual reports (10Ks) to identify (1) firms that disclosed sugar as one of their production inputs and (2) firms that were major sugarcontaining product manufacturers according to their portfolio of products. The $10 \mathrm{~K}$ is the annual report filed by publicly traded companies to fulfill the requirement of financial and business information disclosure by the US Securities and Exchange Commission. Firms that disclosed they used sugar did so in the "Raw Materials," "Risk Factors", or "Products and Brands" sections of the 10Ks. Those firms operating in the US who reported in their 10Ks that they purchased sugar at US prices were selected.

The search procedure resulted in 26 firms included in the analysis, ${ }^{2}$ each with the financial information required to construct the variables included in the regression models. We evaluate the effect of three sugar prices on firm profit: a raw cane sugar price, a refined cane sugar price, and a refined beet sugar price. Sugar prices were obtained from the USDA Sugar and Sweeteners Yearbook tables (USDA ERS 2018). The average of the monthly sugar prices during each quarter was matched to each firm's end-of-quarter calendar month financial data. Observations with negative equity values were excluded from the sample. ${ }^{3}$ The data were treated for the potential effect of outliers. We winsorized the data at the $1 \%$ and $99 \%$ percentiles to minimize the potential effect of outliers (Tukey 1962). A recent review of financial studies shows that the majority of financial studies use winsorizing to treat outliers (Adams et al. 2019).

\footnotetext{
${ }^{1}$ The following are the industry categories from which data was extracted in CRSP/COMPUSTAT (codes in parenthesis): food manufacturing (311); dog and cat food manufacturing (311111); other animal food manufacturing (311119); flour milling (311211); breakfast cereal manufacturing (311230); non-chocolate confectionery manufacturing (311340); chocolate and confectionery manufacturing from cocoa beans (311351); confectionery manufacturing from purchased chocolate (311352); frozen fruit, juice and vegetable manufacturing (311411); frozen specialty food manufacturing (311412); fruit and vegetable canning, pickling and drying (31142); fruit and vegetable canning (311421); specialty canning (311422); dried and dehydrated food manufacturing (311423); fluid milk manufacturing (311511); cheese manufacturing (311513); dry, condensed, and evaporated dairy product manufacturing (311514); ice cream and frozen dessert manufacturing (311520); retail bakeries (311811); commercial bakeries (311812); frozen cakes, pies, and other pastries manufacturing (311813); cookie and cracker manufacturing (311821); dry pasta, dough and flour mixes manufacturing from purchased flour (311824); roasted nuts and peanut butter manufacturing (311911); other snack food manufacturing (311919); flavoring syrup and concentrate manufacturing (311930); mayonnaise, dressing, and other prepared sauce manufacturing (311941); spice and extract manufacturing (311942); perishable prepared food manufacturing (311991); all other miscellaneous food manufacturing (311999); beverage manufacturing (3121); soft drink and ice manufacturing (31211); and soft drink manufacturing (312111).

${ }^{2}$ Agribusinesses included in the sample are Campbell Soup Co., General Mills Inc., Kellogg Co., Hershey Co., Tootsie Roll Industries Inc., Coca-Cola Co., ConAgra Brands Inc., Dean Foods Co., Dr. Pepper Snapple Group Inc., Mondelez International Inc., Monster Beverage Corp., PepsiCo Inc., Post Holdings Inc., Snyder'sLance Inc., B\&G Foods Inc., Ralcorp Holdings Inc., Kraft Heinz Co., Flowers Foods Inc., Hain Celestial Group Inc., J \& J Snack Foods Corp., Smucker (JM) Co., Sherwood Brands Inc., PepsiAmericas, Rocky Mountain Chocolate Factory Inc., Tasty Baking Co., and Wrigley (Wm) Jr. Co.

${ }^{3}$ Observations with negative equity values were removed from the sample because negative equity values would distort some of the financial ratios used as variables in the model specifications (e.g., leverage, book to market). In total only 17 observations with negative equity values were removed.
} 
Table 1 Variables description

\begin{tabular}{lll}
\hline Variable & Description & Formula \\
\hline ROA & Return on assets & ROA $=\frac{\pi M \text { operating income after depreciation }}{\text { Assets }} \times 100$ \\
MTB & Market-to-book & MTB $=\frac{\text { Assets-Equity }+ \text { Stock pricex\#shares }}{\text { Assets }}$ \\
SGA & SG\&A margin & SGA $=\frac{\pi M \text { selling,general and adm.expenses }}{\text { Sales }} \times 100$ \\
ATO & Assets turnover & ATO $=\frac{\pi M \text { sales }}{\text { Assets }}$ \\
Size & Firm size & Size $=\ln$ (Stock price $\times$ \# shares) \\
Growth & Firm growth & Growth $=$ TTM sales growth rate \\
FRisk & Long-term financial risk & FRisk $=\frac{\text { Long term debt }}{\text { Equity }}$ \\
Ura & US raw sugar price & Average monthly US raw cane sugar prices per quarter \\
Ure & US refined sugar price & Average monthly US refined cane sugar prices per quarter \\
Urb & US ref. beet sugar price & Average monthly US refined beet sugar prices per quarter \\
Wra & World raw cane sugar price & Average monthly world raw sugar prices per quarter \\
Wre & World ref. cane sugar price & Average monthly world refined sugar prices per quarter \\
UWpra & US-to-world raw sugar price & $\frac{\text { Ura }}{\text { Wra }}$ \\
UWpre & US-to-world ref. sugar price & $\frac{\text { Ure }}{\text { Wre }}$ \\
UWprb & US-to-world ref. beet s.p. & $\frac{\text { Urb }}{\text { Wre }}$ \\
\hline
\end{tabular}

Notes: TTM stands for trailing twelve months; In is natural logarithm. Source for sugar prices: USDA ERS (2018)

\section{Methods}

Two empirical models are formulated. The first model proxies firm financial performance using a return on asset measure (ROA). The second model proxies firm financial performance using a market-to-book ratio (MTB). Both models are estimated as a function of firm characteristics and US-to-world sugar prices. Three US-to-world sugar price ratios are considered: US-to-world raw cane, US-to-world refined cane, and USto-world refined sugar beet prices. Thus, with two proxies measuring firm financial performance and three different sugar prices, we estimate separately six models. Table 1 provides details regarding the construction of the variables.

\section{Models}

\section{Return on assets specification}

Future return on assets (ROA) is a function of current return on assets (Beaver 1970; Freeman et al. 1982). Since return on assets can be decomposed into the product of profit margin and assets efficiency, ${ }^{4}$ future ROA can be expressed as:

$$
\ln \left(\mathrm{ROA}_{i, t+1}\right)=\beta_{0}+\beta_{1} \cdot \ln \left(\mathrm{Cost}_{i t}\right)+\beta_{2} \cdot \ln \left(\mathrm{SGA}_{i t}\right)+\beta_{3} \cdot \ln \left(\mathrm{ATO}_{i t}\right)+a_{i}+e_{i t}
$$

where ROA is the return on assets of sugar-using firm $i$, for $i=1, \ldots, 26 ; t=$ quarter 1 (Q1) of 2000 to Q4 of 2017 (72 time periods); Cost is the cost margin, measured as the cost of goods sold divided by sales; SG \& A is an operating expenses margin calculated by dividing selling, general and administrative (SG \& A) expenses to sales; ATO is the asset turnover ratio, a measure of asset efficiency estimated as sales divided by assets; the $a_{i}$ are unobserved time-constant effects specific to firms; and $e_{i t}$ is an idiosyncratic

${ }^{4}$ ROA $=\frac{\text { Operating Profit }}{\text { Assets }}=\frac{\text { Operating Profit }}{\text { Sales }} \times \frac{\text { Sales }}{\text { Assets }}=\frac{\text { Sales-Cost of Goods Sold-Operating Expenses }}{\text { Sales }} \times \frac{\text { Sales }}{\text { Assets }}$ 
error with an expected value of zero and a constant variance, with the expected value of the error covariances $E\left(e_{i t} \cdot e_{j s}\right)=0, i \neq j{ }^{5}$ The $\log$-log specification was chosen to interpret the estimates as elasticities of profitability with respect to the covariates (Hill et al. 2011).

To examine the impact of the US sugar program on sugar-using firms' financial performance, the ratio of US-to-world sugar price was added to the specification. Since sugar price is part of Cost, the former variable replaces the later in Eq. (1). Following the RBV theory, firm characteristics that explain profitability, including firm size, growth, and financial risk are included in the specification (Gschwandtner and Hirsch 2018). The model is:

$$
\begin{aligned}
\ln \left(\mathrm{ROA}_{i, t+1}\right)= & \beta_{0}+\beta_{1} \cdot \ln \left(\mathrm{UWp}_{i t}\right)+\beta_{2} \cdot \ln \left(\mathrm{SGA}_{i t}\right)+\beta_{3} \cdot \ln \left(\mathrm{ATO}_{i t}\right)+\beta_{4} \cdot \ln \left(\mathrm{Size}_{i t}\right) \\
& +\beta_{5} \cdot \ln \left(\text { Growth }_{i t}\right)+\beta_{6} \cdot \ln \left(\mathrm{FRisk}_{i t}\right)+a_{i}+e_{i t}
\end{aligned}
$$

where UWp is the ratio of US-to-world sugar price (i.e., relative sugar price). The ratio of the US-to-world sugar price provides insight into how the US sugar price premium relative to the world sugar price influences firm profitability. A relatively larger price ratio indicates that US sugar prices are trading at a greater premium to world sugar prices, which makes US sugar-using firms worse-off by putting them in a competitive disadvantage relative to world sugar-using firms. Three proxies of relative sugar prices were evaluated; a raw cane sugar price ratio (UWpra), a refined cane sugar price ratio (UWpre), and a refined beet sugar price ratio (UWprb). Size is firm size, measured by the market value of the firm; Growth is firm growth, measured as the year to year firm sales growth rate; and FRisk is long-term leverage, a proxy for financial risk, measured by long-term debt divided by equity (Table 1). The substitution of cost of goods sold in Eq. (1) by relative sugar prices in Eq. (2) eliminates the need to model dynamically because the specification (2) modifies the autoregressive specification in (1). ${ }^{6}$ Some recent studies model firm profitability as an autoregressive process (Goddard et al. 2005; Gschwandtner and Hirsch 2018; Hirsch and Gschwandtner 2013). In order to test the null hypotheses of interest in this study, rather than implementing a lagged autoregressive model (i.e., lagged profit on the right-hand side of the equations), we needed to decompose profit (as shown in footnote 4) to introduce US world sugar price into the model.

The pass-through of prices has long been recognized as a practice followed by firms with high market pricing power to maintain margin profits when they face changing cost structures (Datta et al. 2011). For example, one might surmise that when sugarusing firms face higher relative sugar prices, they increase their products' prices or reduce the size of their food products (e.g., smaller candy bars selling at the same price). We test the null hypothesis, $\beta_{1}=0$ with Eq. (2), the elasticity of firm profitability with respect to the relative US-to-world sugar price ratio. Failure to reject the null

\footnotetext{
${ }^{5}$ Variables from firm income statements were transformed from quarterly data to trailing twelve month (TTM) series to benchmark results to annual periods, a practice common in financial analysis (Alberg and Lipton 2017; Myers and Bacon 2004). The TTM were computed by adding together the last four quarter values if information was available for each quarter.

${ }^{6}$ In addition, the use of the sugar price ratio variable instead of cost of goods sold allows us to test the ratio of US-to-world sugar price in order to evaluate the effect of the US sugar program on sugar-using firms. At the industry level, sugar prices represent a relatively low portion of cost of goods sold (Triantis 2016). Firms do not disclose the cost of sugar consumed.
} 
hypothesis suggests that changes in firm profitability are unrelated with US sugar-using firms paying a premium for US sugar compared to if they had access to the world sugar market. The alternative, $\beta_{1} \neq 0$, suggests that (1) US sugar-using firms pass on higher costs to consumers when relative prices increase or do not pass on discounts to consumers when relative sugar prices decrease $\left(\beta_{1}>0\right)$, or (2) US sugar-using firms absorb higher costs when relative prices increase without passing on to consumers $\left(\beta_{1}<0\right){ }^{7}$

\section{Market-to-book specification}

We also measure investors' reaction to sugar price changes by testing how firms' market values change. In this specification of firm financial performance, we replace ROA as the dependent variable in Eq. (2) with the market-to-book ratio (MTB). The marketto-book ratio is a firm's market value relative to its book value. The firm's market value is estimated as total assets minus the book value of equity plus market capitalization, and total assets proxy firm book value (Harford et al. 2008). Thus, the MTB is an alternative measure of firm performance that combines accounting figures with market valuations (Chung and Pruitt 1994; Harford 1999; Wernerfelt and Montgomery 1988). Market valuations are determined according to investors' reaction through stock prices. Previous research documents a positive relationship between the market-to-book ratio and accounting profits (Bianconi and Yoshino 2017; Carosi 2016). Financial theory also suggests that firms with higher MTB values have greater growth opportunities because investors discount future profits in stock prices (Fama and French 1995; Hovakimian et al. 2001). The market-to-book specification is:

$$
\begin{aligned}
\ln \left(\mathrm{MTB}_{i, t+1}\right)= & \beta_{0}+\beta_{1} \cdot \ln \left(\mathrm{UWp}_{i t}\right)+\beta_{2} \cdot \ln \left(\mathrm{SGA}_{i t}\right)+\beta_{3} \cdot \ln \left(\mathrm{ATO}_{i t}\right)+\beta_{4} \cdot \ln \left(\mathrm{Size}_{i t}\right) \\
& +\beta_{5} \cdot \ln \left(\text { Growth }_{i t}\right)+\beta_{6} \cdot \ln \left(\mathrm{FRisk}_{i t}\right)+a_{i}+e_{i t}
\end{aligned}
$$

where the right-hand side variables, firm fixed effects, and error term are defined in Eq. (2).

\section{Estimation}

The regression models of Eqs. (2) and (3) are individual effect models (Cameron and Trivedi 2006), where the $a_{i} \mathrm{~s}$ are random unobserved firm-specific effects. The individual effects model assumes that $E\left(y_{i t} \mid a_{i}, X_{i t}\right)=a_{i}+X_{i t} \beta$, maintaining the assumption of strict orthogonality $E\left(e_{i t} \mid a_{i}, X_{i t}\right)=0$, where $y_{i t}\left(X_{i t}\right)$ are the dependent (independent) variables. The time-invariant firm-specific effects may be arbitrarily correlated with the financial variables included as regressors (Wooldridge 2002). For this analysis, treating each random effect as separate firm-specific intercepts is inappropriate because we cannot treat the set of sugar-using firms analyzed as a randomly drawn sample from a population of firms (Wooldridge 2013). The collinearity condition index was estimated

\footnotetext{
${ }^{7}$ The assumption is that US sugar-using firms will make an output price decision (e.g., change or keep output prices) when changes in input prices make them worse-off (i.e., in competitive disadvantage) relative to world sugar-using firms. This situation occurs when US-to-world sugar price ratios increase. Price ratios increase when both US and world prices increase but US prices increase at higher rate or when both US and world prices decrease with US sugar prices decreasing at a lower rate. Sugar-using firms claim that the difference between world and US sugar prices negatively impact profits. On other hand, when price ratios decrease, US firms are better-off relative to world firms. In this second situation, no changes in output prices are assumed.
} 
to ensure that collinearity was not affecting the parameter estimates or their standard errors (Belsey et al. 1980).

An Eicker-Huber-White covariance matrix robust to arbitrary forms of heteroscedasticity was used to calculate standard errors of the estimates (White 1980). The assumption that $E\left(e_{i t} \cdot e_{j s}\right)=0$ for $i \neq j$ was maintained but left unrestricted for within-firm errors (Cameron and Trivedi 2006). The null hypothesis that the $k$ th explanatory variable is different from zero is tested with a $t$ statistic. For the cluster robust covariance estimator, the degrees of freedom (df) for $t$ tests are calculated as the number of firms included in the sample less one ( $\mathrm{df}=25$ for the ROA model, and 24 for the market-tobook specification) (Cameron and Trivedi 2006).

\section{Ex post power of the tests}

A common approach in the empirical applications is to test the robustness of a model by estimating several specifications and using those estimates for hypothesis testing. A supplemental assessment entails determining ex post the power of model tests (Brown et al. 2019; Wojan et al. 2014). The power of a test is one minus the probability of observing a type II error. In the present application, a type II error is the likelihood of failing to reject the null hypothesis that the sugar price ratio has no effect on firm financial performance, when in fact the converse is true. In other words, the ex post power of a test provides supporting evidence with respect to conclusions drawn from the inductive exercise of null hypothesis statistical testing (Wojan et al. 2014). In the absence of power, a test result of "not significant" does not unequivocally translate to "no effect on financial performance". Power is a function of sample size, the inherent variability of the data, and a posited effect size. Holding sample size and its variance constant, an effect size of an estimate is the value of a parameter that corresponds with a "low" type II error. Empirical research typically associates a low type II error rate with a power of 0.80 (Bayarri et al. 2016; Cohen 1988). Under the null hypothesis, the power of a test is the nominal size of the test, i.e., the type I error rate, which is determined by the researcher. Common type I error rates are 0.01, 0.05, and 0.10.

We modify Brown et al.'s (2019) procedure for determining the ex post power of the test that US-to-world sugar prices are, ceteris paribus, uncorrelated with firm financial performance. The null hypothesis is a two-tailed test. We set the nominal size of the test (i.e., a type I error rate-or the probability of rejecting the null hypothesis when it is false) to 0.05 . For each model specification above, we resample, with replacement, the residuals of the regressions holding the design matrix $X$ and the sample used in the individual effects regressions fixed to determine the power of the test.

The first step of the resampling procedure entails selecting the effect sizes of $\beta_{1}$ (the elasticity of firm financial performance with respect to the US-to-world sugar price). Since there were no strong priors identified regarding the appropriate effect size in the literature, we evaluate power over a range of effect sizes under the alternative hypothesis $\left(H_{A}\right)$ from $\bar{\beta}_{1}=-0.35$ to 0.35 in 0.01 increments. The range should be wide enough such that at the tails the power of the two-tailed test should converge to one. Step 2 requires reconstructing the model's data generating process. A simulation procedure similar to a percentile $t$ test (Cameron and Trivedi 2006) is modified for the individual effects regression. The residual bootstrap applied here entails the following sequence: 
(a) For effect size $\bar{\beta}_{1}$, resample with replacement from the set of residuals $\left(\hat{e}_{i t}\right)$ from the individual effects regression, stratifying on firms. Stratifying the resampling procedure by firms maintains the assumption of zero correlation of residuals with other firms.

(b) Calculate $y_{i t}^{*}=\hat{a}_{i}+X_{i t} \hat{\beta}+\hat{e}_{i t}^{*}$, replacing $\hat{\beta}_{1}$ with $\bar{\beta}_{1}$.

(c) Regress $X_{i t}$ on $y_{i t}^{*}$ as an individual effects regression, recovering $\hat{\beta}_{1}^{*}$.

(d) Calculate the $t$-statistic $\left(t^{*}\right)$ using cluster robust standard errors for $\hat{\beta}_{1}^{*}$ under the null hypothesis, $H_{0}: \beta_{1}=0$.

(e) For a 2-tailed test and a type I error rate 0.05, if $\left|t^{\prime \prime}\right|>t_{0.05, g-1}$ ( $g$ is the number of firms in the sample), then tally rejection of the null hypothesis with a "1" (" 0 " otherwise).

(f) Return to step (a).

(g) Repeat $M$ times.

For all models the critical $t$ value is $t_{0.05, g-1} \approx 2.06$. The power of the test is determined as the number of times the null hypothesis is rejected divided by the number of simulations for each effect size evaluated. We set $M=1000$ iterations for each model specification under each effect size evaluated. In contrast to theoretical two-tailed power curves, the tails of the simulated ex post power curves may be asymmetric due to resampling and the data's variability. The analysis over the different effect sizes identifies the upper and lower thresholds of the effect size past which the type II error probability is less than 0.20 .

\section{Descriptive statistics}

The average annual ROA for sugar-using agribusinesses is 13.6\% (Table 2), which is higher compared to ROAs for all agribusinesses (Katchova and Enlow 2013; Schumacher and Boland 2005; Trejo-Pech et al. 2016; Trejo-Pech et al. 2008). ${ }^{8}$ Sugar-using agribusinesses therefore represent a subset of highly profitable firms (Triantis 2016). The average market-to-book value is 2.3 , suggesting that investors value these firms over their book values. A previous study documented that the market-to-book value for the agribusiness sector exceed 3.0 (Trejo-Pech et al. 2015), indicating that sugar-using agribusinesses are comparatively mature companies with fewer growth opportunities relative to the composite agribusiness sector. Firms in the sample grow sales by $5.2 \%$ annually and have a low leverage equal to a 0.13 long-term debt to equity ratio. Operating expenses margin is $25 \%$ of total sales. Sugar-using firms sell, on average, more than their total assets by a factor of 1.1. US sugar prices ranged between 1.9 and 2.0 times the world sugar price from 2000 to 2017.

Table 3 summarizes the Spearman correlation coefficients of variables used in the regression models; that is, next period ROA and MTB and the rest of variables indexed at the current period, and all variables in natural logs. Next period return on assets are negatively correlated with this period financial risk and sales growth, but positively correlated with this period asset turnover, market-to-book value, SG \& A, and firm size. The positive correlation between SG \& A and next period ROA may imply that some

${ }^{8}$ Those previous studies are a reference to compare our results since all use data from COMPUSTAT and report average ROA over long periods. However, we recognize that our sample is not directly comparable because they study different periods. 
Table 2 Descriptive statistics of sugar-using publicly traded firms from Q1 2000 to Q4 2017

\begin{tabular}{llllll}
\hline Variable & Obs & Mean & Std. Dev. & Min & Max \\
\hline ROA & 1513 & 13.62 & 7.90 & -3.50 & 43.39 \\
MTB & 1543 & 2.33 & 1.34 & 0.95 & 8.03 \\
SGA & 1535 & 24.66 & 8.54 & 10.02 & 43.21 \\
ATO & 1545 & 1.08 & 0.48 & 0.32 & 3.01 \\
Size & 1543 & 8.72 & 2.15 & 3.23 & 12.38 \\
Growth & 1527 & 5.21 & 10.69 & -19.19 & 53.80 \\
FRisk & 1541 & 0.13 & 0.11 & 0.00 & 0.48 \\
UWpra & 1562 & 2.00 & 0.69 & 1.14 & 3.90 \\
UWpre & 1562 & 2.04 & 0.45 & 1.19 & 3.22 \\
UWprb & 1562 & 1.92 & 0.42 & 1.14 & 2.89 \\
\hline
\end{tabular}

Notes: Variable definitions are shown in Table 1. Quarterly financial data was obtained from CRSP/COMPUSTAT from the first quarter of 2000 to the fourth quarter of 2017. Observations with negative common equity were removed from the sample. We winsorized the data at the $1 \%$ and $99 \%$ percentiles (Adams et al. 2019; Tukey 1962). Monthly sugar prices were obtained from the USDA sugar and sweeteners yearbook tables.

selling expenditures, such as advertising expenses, help increase revenues and consequently firm profits. It is common for firms to set their advertising expenditures as a function of sale revenues. The high correlation between ROA and MTB (0.83) supports the proposition to use both variables as alternative proxies of firm financial performance. The correlations among US raw cane, US refined cane, and US refined beet sugar to world price ratios are high, ranging from 0.77 to 0.95 . The high correlation among these relative prices suggest that use of any of these sugar price ratios on testing the effect of sugar prices on firm profitability will likely generate similar results, regardless of the type of sugar or combination of types of sugar these firms purchase.

\section{Results}

Regression results

Table 4 summarizes the results of the accounting returns regression (Eq. 2) with $\mathrm{ROA}_{t+1}$ the dependent variable. The models explain around $30 \%$ of the variation of next period ROA. A 1\% increase in asset turnover, the asset efficiency component of the models, increases next period ROA by $0.60 \%$. Similarly, the larger the firm is, the

Table 3 Spearman correlation coefficients

\begin{tabular}{llllllllll}
\hline & ROA & MTB & SGA & ATO & Size & Growth & FRisk & UWpra & UWpre \\
\hline MTB & $0.8330^{*}$ & & & & & & & \\
SGA & $0.3387^{*}$ & $0.3584^{*}$ & & & & & & \\
ATO & $0.3028^{*}$ & $0.1804^{*}$ & $0.2358^{*}$ & & & & & \\
Size & $0.2947^{*}$ & $0.3365^{*}$ & $0.1758^{*}$ & $-0.4018^{*}$ & & & & \\
Growth & $-0.1791^{*}$ & $-0.1626^{*}$ & $-0.0996^{*}$ & -0.0123 & $-0.1412^{*}$ & & & \\
FRisk & $-0.5109^{*}$ & $-0.6115^{*}$ & $-0.3790^{*}$ & $-0.2673^{*}$ & $0.1001^{*}$ & $0.0887^{*}$ & & \\
UWpra & 0.039 & $-0.0690^{*}$ & $0.1078^{*}$ & $0.1818^{*}$ & $-0.1753^{*}$ & $0.0721^{*}$ & $-0.0794^{*}$ & & \\
UWpre & 0.055 & $-0.0919^{*}$ & $0.1121^{*}$ & $0.1969^{*}$ & $-0.1811^{*}$ & $0.091^{*}$ & $-0.0915^{*}$ & $0.8671^{*}$ & \\
UWprb & 0.0495 & $-0.0769^{*}$ & $0.0787^{*}$ & $0.1343^{*}$ & $-0.1453^{*}$ & $0.0777^{*}$ & $-0.0809^{*}$ & $0.7726^{*}$ & $0.9503^{*}$ \\
\hline
\end{tabular}

Notes: Variable definitions are in Table 1. All variables are in natural logarithm, ROA and MTB are expressed at $t+1$ and other variables at $t$, as in models (2) and (3)

*Statistical significance level at $5 \%$ 
Table 4 Regression with $\mathrm{ROA}_{t+1}$ as the dependent variable

\begin{tabular}{|c|c|c|c|}
\hline Variable & Model 1 & Model 2 & Model 3 \\
\hline \multirow[t]{2}{*}{$\ln (S G A)$} & -0.003 & -0.005 & 0.006 \\
\hline & $(0.146)$ & $(0.147)$ & $(0.147)$ \\
\hline$t$ & -0.02 & -0.03 & 0.04 \\
\hline \multirow[t]{2}{*}{ In(ATO) } & $0.600^{* * *}$ & $0.586^{* * *}$ & $0.581^{* * *}$ \\
\hline & $(0.179)$ & $(0.177)$ & $(0.178)$ \\
\hline$t$ & 3.35 & 3.31 & 3.26 \\
\hline \multirow[t]{2}{*}{ In(Size) } & $0.153^{* * *}$ & $0.154^{* * *}$ & $0.140^{* * *}$ \\
\hline & $(0.041)$ & (0.039) & (0.039) \\
\hline$t$ & 3.76 & 3.98 & 3.62 \\
\hline \multirow[t]{2}{*}{ In(Growth) } & 0.010 & 0.007 & 0.008 \\
\hline & $(0.011)$ & $(0.010)$ & $(0.011)$ \\
\hline$t$ & 0.87 & 0.71 & 0.76 \\
\hline \multirow[t]{2}{*}{ In(FRisk) } & $-0.056^{* * *}$ & $-0.056^{* * *}$ & $-0.058^{* * *}$ \\
\hline & $(0.016)$ & $(0.015)$ & $(0.016)$ \\
\hline$t$ & -3.59 & -3.64 & -3.75 \\
\hline \multirow[t]{2}{*}{ In(UWpra) } & $0.179 * *$ & & \\
\hline & $(0.068)$ & & \\
\hline$t$ & 2.62 & & \\
\hline \multirow[t]{2}{*}{ In(UWpre) } & & $0.259^{* *}$ & \\
\hline & & (0.099) & \\
\hline$t$ & & 2.61 & \\
\hline \multirow[t]{2}{*}{ In(UWprb) } & & & $0.199^{* * *}$ \\
\hline & & & $(0.068)$ \\
\hline$t$ & & & 2.92 \\
\hline \multirow[t]{2}{*}{ Constant } & 0.861 & 0.793 & 0.926 \\
\hline & (0.609) & $(0.574)$ & $(0.586)$ \\
\hline$t$ & 1.41 & 1.38 & 1.58 \\
\hline Observations & 953 & 953 & 953 \\
\hline \# of firms & 26 & 26 & 26 \\
\hline$R$-squared & 0.297 & 0.295 & 0.284 \\
\hline$F$ value & 54.42 & 71.30 & 68.58 \\
\hline
\end{tabular}

Notes: Robust standard errors in parentheses. ${ }^{* * *} p<0.01,{ }^{* *} p<0.05,{ }^{*} p<0.1$. Reported $R^{2}$ are "within" $R^{2}$ statistics. Variable definitions are in Table 1. The data were winsorized at the 1\% and 99\% percentiles (Adams et al. 2019; Tukey 1962). The Akaike Information Criterion (AIC) and Bayesian Information (BIC) tests confirmed that winsorized data explain better the models

more profitable. In contrast, the more financial risk a firm undertakes the less profitable it is. These results are statistically significant at the $1 \%$ level across the three ROA models.

The three sugar price ratio estimates (cane raw, cane refined, and beet refined) are also shown in Table 4. The ratio of US-to-world sugar prices has a positive effect on firm profitability at the $5 \%$ level of significance, suggesting that as US prices increase relative to world prices, sugar-using firms are more profitable. This suggests that US sugar-using firms pass on higher costs to consumers when the relative US-to-world sugar price increases or they do not pass on discounts to consumers when relative USto-world sugar prices decrease (Datta, Iskandar-Datta, and Sharma 2011). A 1\% 
increase in the ratio of the US-to-world raw sugar price, for instance, increases next period ROA by $0.18 \%$, ceteris paribus.

The regression models were also estimated using the market-to-book value, MTB, as a dependent variable (Table 5). Unlike ROA, the MTB contains accounting data and market data, thus capturing investor reactions to changes in sugar prices through stock prices. Similar to the ROA models, firm asset efficiency and firm size positively explain future MTB, and financial risk is negatively related to future MTB. In addition, an increase in the SG\&A margin positively affects MTB, suggesting that investors value the increase of certain expenses relative to revenues. Advertising expenses could be one of those expenses. These parameters are statistically significant at the $1 \%$ level, with the

Table 5 Regression with $\mathrm{MTB}_{t+1}$ as the dependent variable

\begin{tabular}{|c|c|c|c|}
\hline Variable & Model 1 & Model 2 & Model 3 \\
\hline \multirow[t]{2}{*}{$\ln (S G A)$} & $0.237^{* * *}$ & $0.226^{* * *}$ & $0.224^{* * *}$ \\
\hline & $(0.082)$ & $(0.080)$ & $(0.080)$ \\
\hline$t$ & 2.90 & 2.81 & 2.81 \\
\hline \multirow[t]{2}{*}{$\ln ($ ATO) } & $0.545^{* * *}$ & $0.520^{* * *}$ & $0.513^{* * *}$ \\
\hline & $(0.097)$ & $(0.093)$ & $(0.092)$ \\
\hline$t$ & 5.64 & 5.59 & 5.59 \\
\hline \multirow[t]{2}{*}{ In(Size) } & $0.275^{* * *}$ & $0.251^{* * *}$ & $0.237^{* * *}$ \\
\hline & $(0.045)$ & $(0.046)$ & $(0.046)$ \\
\hline$t$ & 6.14 & 5.48 & 5.18 \\
\hline \multirow[t]{2}{*}{ In(Growth) } & 0.005 & 0.005 & 0.006 \\
\hline & $(0.007)$ & $(0.007)$ & $(0.007)$ \\
\hline$t$ & 0.65 & 0.66 & 0.84 \\
\hline \multirow[t]{2}{*}{ In(FRisk) } & $-0.090^{* * *}$ & $-0.095^{* * *}$ & $-0.098^{* * *}$ \\
\hline & $(0.015)$ & $(0.016)$ & $(0.017)$ \\
\hline$t$ & -5.89 & -5.86 & -5.83 \\
\hline \multirow[t]{2}{*}{ In(UWpra) } & $0.153^{* * *}$ & & \\
\hline & $(0.046)$ & & \\
\hline$t$ & 3.28 & & \\
\hline \multirow[t]{2}{*}{ In(UWpre) } & & $0.117^{*}$ & \\
\hline & & $(0.062)$ & \\
\hline$t$ & & 1.88 & \\
\hline \multirow[t]{2}{*}{ In(UWprb) } & & & 0.056 \\
\hline & & & $(0.047)$ \\
\hline$t$ & & & 1.18 \\
\hline \multirow[t]{2}{*}{ Constant } & $-2.807^{* * *}$ & $-2.563^{* * *}$ & $-2.395^{* * *}$ \\
\hline & $(0.501)$ & $(0.517)$ & $(0.533)$ \\
\hline$t$ & -5.60 & -4.95 & -4.49 \\
\hline Observations & 977 & 977 & 977 \\
\hline \# of firms & 26 & 26 & 26 \\
\hline$R$-squared & 0.647 & 0.624 & 0.617 \\
\hline$F$ value & 112.92 & 98.03 & 93.48 \\
\hline
\end{tabular}

Notes: Robust standard errors in parentheses. ${ }^{* * *} p<0.01,{ }^{* *} p<0.05,{ }^{*} p<0.1$. Reported $R^{2}$ are "within" $R^{2}$ statistics. Variable definitions are in Table 1. The data were winsorized at the $1 \%$ and $99 \%$ percentiles (Adams et al. 2019; Tukey 1962). The $\mathrm{AIC}$ and BIC tests confirmed that winsorized data explain better the models 
models explaining around $60 \%$ of variance. Like in the ROA models, results reject the null hypothesis in two out of the three sugar price ratio estimates in the MTB models but fail to reject the null for the refined sugar beet estimate. Relative sugar price estimates are positive and statistically significant at the 1\% (raw sugar) and 10\% (refined sugar cane) level of significance. Thus, like with the ROA specification, MTB results suggest that US sugar-using firms pass on higher costs to consumers when relative USto-world prices increase or do not pass on discounts to consumers when relative USto-world sugar prices decrease.

\section{Ex post power of the tests}

The above results suggest that changes in the US-to-world sugar prices are likely to positively affect sugar-using firm financial performance as evidenced by five of the six specifications (Tables 4 and 5). We tested the ex post power of the elasticities reported in Tables 4 and 5 using Brown et al.'s procedure. The following discussion reports the power of the tests for $H_{0}: \beta_{1}=0$, in the manuscript. The effect sizes corresponding with a (2-tailed) power test are reported in Table 6 .

Regarding the results of Table 4, ROA models, the ex post power of these tests is above 0.80 . One can confidently conclude that as US prices increase relative to world sugar prices, this has a positive effect on US sugar-using firm profitability. The effect sizes for each test indicates the threshold one could expect to observe a powerful test (Table 6). All ROA US-to-world sugar price ratios estimates in Table 4 are past the thresholds in Table 6.

Concerning the MTB models in Table 5, the ex post power of these tests was equivalent to the tests' size above 0.8 only for the first specification, raw cane sugar. Results for the refined cane sugar and refined beet sugar relative prices have low ex post power. This implies that even though we find that the relationship between refined beet sugar relative prices and firm financial performance is not statistically significant, this does not translate to "no effect on financial performance" due to the low power of the ex post test.

\section{Conclusions}

The world sugar market is often referred to as the most distorted commodity market in the world and consists primarily of subsidized, "dumped," sugar. World raw sugar

Table 6 Effect sizes and expost-post power test

\begin{tabular}{|c|c|c|c|c|}
\hline \multirow[t]{2}{*}{ Variable } & \multicolumn{2}{|l|}{$\mathrm{ROA}$} & \multicolumn{2}{|l|}{ MTB } \\
\hline & $\begin{array}{l}\text { Lower effect size } \\
\text { threshold }\end{array}$ & $\begin{array}{l}\text { Upper effects size } \\
\text { threshold }\end{array}$ & $\begin{array}{l}\text { Lower effect size } \\
\text { threshold }\end{array}$ & $\begin{array}{l}\text { Upper effects size } \\
\text { threshold }\end{array}$ \\
\hline In(UWpra) & -0.18 & 0.16 & -0.11 & 0.12 \\
\hline Power & & 0.85 & & 0.99 \\
\hline In(UWpre) & -0.27 & 0.24 & -0.16 & 0.16 \\
\hline Power & & 0.90 & & 0.28 \\
\hline In(UWprb) & -0.20 & 0.18 & -0.13 & 0.13 \\
\hline Power & & 0.91 & & 0.03 \\
\hline
\end{tabular}

Notes: Variable definitions are in Table 1. Null hypothesis: relative sugar price does not affect sugar-using firm financial performance (ROA and MTB). The analysis over the different effect sizes identifies the upper and lower thresholds of the effect size past which the type II error probability is less than 0.20 . The lower and upper thresholds correspond with a power $>0.80$ (a type II error rate $<0.20$ ). Ex post power of tests evaluated at a nominal type I error rate of 0.05 
prices trade at lower prices than US raw sugar prices because the US sugar program protects domestic sugar producers from competing against the heavily subsidized world sugar market. Sugar-using businesses argue that the US sugar program decreases their profits. Firms claim that as the US price of sugar increases relative to the world sugar price, this negatively impacts their profits. To test the hypothesis that relative US-toworld sugar prices affect the profits of US sugar-using businesses, we determined if relative sugar prices impacted, ceteris paribus, sugar-using firms' profits and market-tobook values. In five of the six model specifications, relative sugar prices did influence sugar-using firm profitability. Thus, in five of six model specifications, results rejected the null hypothesis that the relative US-to-world sugar prices had no effect on sugarusing firm profits at a conventional level of significance. However, results were unexpected in that as US sugar prices became more expensive relative to world sugar prices, sugar-using firm financial performance improved. This suggests that US sugar-using firms pass on higher costs to consumers when relative prices increase or do not pass on discounts to consumers when relative sugar prices decrease. Ex post statistical tests further show that four out the six model specification are powerful, which indicates that the probability of a type II error is low.

Results of this analysis indicate that the US sugar program does not impede publicly traded sugar-using firm financial performance. However, it should be noted that this study only examined publicly traded companies and did not examine the impact of the US sugar program has on private (most likely smaller and medium sized) sugar-using companies. This is a limitation of our analysis; however, we only had access to firm financial data of publicly traded companies. This research provides a framework for examining the impact of the US sugar program on sugar-using company firm performance. Future research could expand this analysis to private firms and further examine how sugar-using firms pass through sugar costs to consumers.

\footnotetext{
Acknowledgements

Carlos Trejo-Pech acknowledges that this work was partially supported by the USDA National Institute of Food and Agriculture, Hatch Multi-State project 1012420. Lambert's research was supported by the Oklahoma State University Sparks Endowed Chair in Agribusiness and Oklahoma Agriculture Experiment Station.
}

\section{Authors' contributions}

CTP prepared the initial draft of the manuscript and led subsequent edits by the rest of authors. CTP also proposed and ran the regression models in STATA. KD provided the motivation for the manuscript; she wrote the "Introduction" and "Literature review" sections related to the sugar program and helped editing the complete manuscript. DL wrote the power of test section mainly, coded and ran the simulations in STATA for the power of test analysis, and helped editing/improving the manuscript. VS helped with the data section mainly, collecting data from COMPUSTAT, CRSP, USDA, and filtering the sample by inspecting firms' annual reports submitted to the Securities and Exchange Commission. The author(s) read and approved the final manuscript.

\section{Authors' information}

Carlos J. Omar Trejo-Pech is an Assistant Professor of Agribusiness Finance at the University of Tennessee, Knoxville, TN; and was professor of finance at Facultad de Ciencias Económicas y Empresariales, Universidad Panamericana, Zapopan, Jalisco, México. He obtained his PhD in Food and Resource Economics, with minor in finance, from the University of Florida, Gainesville, FL, in 2007, and a Master in Finance from Mississippi State University in 2000. Trejo-Pech's current areas of research include agribusiness finance and agribusiness management. Trejo-Pech's research work has been published in journals such as the International Food and Agribusiness Management Review, Agribusiness: An International Journal, American Journal of Agricultural Economics, Agricultural Finance Review, and Canadian Journal of Agricultural Economics. Email: ctrejope@utk.edu. Department of Agricultural and Resource Economics, 308-D Morgan Hall, 2621 Morgan Circle, Knoxville, TN 37996, USA

Karen L. DeLong is an Assistant Professor of Agricultural and Resource Economics at the University of Tennessee. She earned her Ph.D. in Business Administration (Agribusiness) from the W. P. Carey School of Business at Arizona State University in 2014; her M.S. in Agricultural, Food and Resource Economics at Michigan State University in 2010; and a B.S. in Mathematics and Economics at Western Michigan University in 2008. Her current research interests include agricultural and food policy, international trade, livestock economics, and experimental economics. Email: klewis3 
9@utk.edu. Department of Agricultural and Resource Economics, 302-G Morgan Hall, 2621 Morgan Circle, Knoxville, TN 37996, USA

Dayton M. Lambert is a Professor and Sparks Chair in Agribusiness in the Department of Agricultural Economics at Oklahoma State University. He earned his Ph.D. in Agricultural Economics from Purdue University, his M.S. in Fisheries and Allied Aquacultures at Auburn University, and his M.A. in Cultural Anthropology from Rutgers University. His current research interests include production economics, econometrics, and regional economic development. Email: dayton.lambert@okstate.edu. Professor and Sparks Chair of Agribusiness, Department of Agricultural Economics, Oklahoma State University, Stillwater, OK, 74074, USA

Vasileios Siokos was a Research Assistant in the Department of Agricultural and Resource Economics at the University of Tennessee, Knoxville, in 2017-2017. He earned his M.S. in agricultural economics from the University of Tennessee, Knoxville, TN, in the summer of 2018. He has a BSc from the Department of Agricultural Economics and Rural Development of the Agricultural University of Athens, Greece. Current research areas include agricultural economics. Email: vsiokos@vols.utk.edu. Department of Agricultural and Resource Economics, 2621 Morgan Circle, Knoxville, TN 37996, USA

\section{Funding}

No funding was received to conduct this study.

\section{Availability of data and materials}

The financial data generated and/or analyzed during the current study cannot be made publicly available because they were obtained from Wharton Research Data Services (https://wrds-web.wharton.upenn.edu/wrds/). In particular, data processed in this study are mainly from the following two datasets: Standard \& Poor's COMPUSTAT and the Center for Research in Security Prices at the University of Chicago (CRSP). Both, COMPUSTAT and CRSP are available through WRDS with university subscription only and restricted to faculty with researcher appointments and graduate students.

\section{Competing interests}

The authors declare that they have no competing interests.

\section{Author details}

${ }^{1}$ Department of Agricultural \& Resource Economics, University of Tennessee, Knoxville, TN 37919, USA. ${ }^{2}$ Department of Agricultural Economics, Oklahoma State University, Stillwater, OK 74074, USA.

Received: 14 November 2018 Accepted: 19 May 2020

Published online: 22 June 2020

\section{References}

Abler D, Beghin J, Blandford D, Elobeid A (2008) Changing the U.S. sugar program into a standard crop program: consequences under the North American Free Trade Agreement and Doha. Review of Agricultural Economics 30(1):82102 https://doi.org/10.2307/30224835

Adams J, Hayunga D, Mansi S, Reeb D, Verardi V (2019) Identifying and treating outliers in finance. Financial Management 48(2):345-384 https://doi.org/10.1111/fima.12269

Alberg J, Lipton Z (2017) Improving factor-based quantitative investing by forecasting company fundamentals. Presented at the 31st Conference on Neural Information Processing Systems (NIPS 2017), Long Beach Retrieved from https://arxiv.org/ $\mathrm{abs} / 1711.04837$

Bayarri M, Benjamin D, Berger J, Sellke T (2016) Rejection odds and rejection ratios: a proposal for statistical practice in testing hypotheses. Journal of Mathematical Psychology 72:90-103 https://doi.org/10.1016/j.jmp.2015.12.007

Beaver W (1970) The time series behavior of earnings. Journal of Accounting Research 8:62-99 https://doi.org/10.2307/ 2674693

Beghin J, Elobeid A (2015) The impact of the U.S. sugar program redux. Applied Economic Perspectives and Policy 37(1):1-33 https://doi.org/10.1093/aepp/ppu028

Beghin J, Osta B, Cherlow J, Mohanty S (2001) The cost of the U.S. sugar program revisited. Contemporary Economic Policy 21(1):106-116 https://doi.org/10.1093/cep/21.1.106

Belsey D, Kuh E, Welsh R (1980) Regression diagnostics: identifying influential data and sources of collinearity. Wiley, New York

Bianconi M, Yoshino J (2017) Valuation of the worldwide commodities sector. Studies in Economics and Finance 34(4):555579 https:/doi.org/10.1108/SEF-04-2016-0095

Brown J, Lambert D, Wojan T (2019) The effect of the conservation reserve program on rural economies: deriving a statistical verdict from a null finding. American Journal of Agricultural Economics 101(2):528-540 https://doi.org/10.1093/ajae/ aay046

Cameron A, Trivedi P (2006) Microeconometrics. Cambridge University Press, Cambridge

Carosi A (2016) Do local causations matter? The effect of firm location on the relations of ROE, R\&D, and firm SIZE with MARKET-TO-BOOK. Journal of Corporate Finance 41:388-409 https://doi.org/10.1016/j.jcorpfin.2016.10.008

Chaddad FR, Mondelli MP (2013) Sources of firm performance differences in the US food economy. Journal of Agricultural Economics 64(2):382-404 https://doi.org/10.1111/j.1477-9552.2012.00369.x

Chatenay, P. (2013). Government support and the Brazilian sugar industry (No. April 17 th, 2013; pp. 1-25). Retrieved from ProSunergy (UK) Ltd, prepared for the American Sugar Alliance website: https://sugaralliance.org/wp-content/uploads/2 015/08/gov-support.pdf

Chung K, Pruitt S (1994) A simple approximation of Tobin's q. Financial Management 23(3):70-74 https://doi.org/10.2307/ 3665623

Cohen J (1988) Statistical power analysis for the behavioral sciences, 2nd edn. Lawrence Erlbaum, New Jersey 
Datta S, Iskandar-Datta M, Sharma V (2011) Product market pricing power, industry concentration and analysts' earnings forecasts. Journal of Banking \& Finance 35(6):1352-1366 https://doi.org/10.1016/j.jbankfin.2010.10.016

Elobeid A, Beghin J (2006) Multilateral trade and agricultural policy reforms in sugar markets. Journal of Agricultural Economics 57(1):23-48 https://doi.org/10.1111/j.1477-9552.2006.00030.x

Fama E, French K (1995) Size and book-to-market factors in earnings and returns. The Journal of Finance 50(1):131-155 https://doi.org/10.2307/2329241

Freeman R, Ohlson J, Penman S (1982) Book rate-of-return and prediction of earnings changes: an empirical investigation. Journal of Accounting Research 20(2):639-653 https://doi.org/10.2307/2490890

Goddard J, Tavakoli M, Wilson J (2005) Determinants of profitability in European manufacturing and services: evidence from a dynamic panel model. Applied Financial Economics 15(18):1269-1282

Gschwandtner A, Hirsch S (2018) What drives firm profitability? a comparison of the US and EU food processing industry. The Manchester School 86(3):390-416 https://doi.org/10.1111/manc.12201

Harford J (1999) Corporate cash reserves and acquisitions. The Journal of Finance 54(6):1969-1997 Retrieved from JSTOR

Harford J, Mansi SA, Maxwell WF (2008) Corporate governance and firm cash holdings in the US. Journal of Financial Economics 87(3):535-555 https://doi.org/10.1016/j.jfineco.2007.04.002

Hill R, Griffiths W, Lim G (2011) Principles of econometrics (4th Edition). Wiley, United States

Hirsch S, Gschwandtner A (2013) Profit persistence in the food industry: evidence from five European countries. European Review of Agricultural Economics 40(5):741-759 https://doi.org/10.1093/erae/jbt007

Hirsch S, Schiefer J, Gschwandtner A, Hartmann M (2014) The determinants of firm profitability differences in EU food processing. Journal of Agricultural Economics 65(3):703-721 https://doi.org/10.1111/1477-9552.12061

Hodari, D. (2018). Sugar low: commodity plummets on surplus. The Wall Street Journal, May 1, 2018. Retrieved from https:// blogs.wsj.com/moneybeat/2018/05/01/sugar-low-commodity-plummets-on-surplus/

Hovakimian A, Opler T, Titman S (2001) The debt-equity choice. The Journal of Financial and Quantitative Analysis 36(1):1-24 https://doi.org/10.2307/2676195

Hudson D (2019) An examination of foreign subsidies and trade policies for sugar. Texas Tech University, (BP-19-01), pp 1-32

Katchova A, Enlow S (2013) Financial performance of publicly-traded agribusinesses. Agricultural Finance Review 73(1):58-73. https://doi.org/10.1108/00021461311321311

Kennedy P, Petrolia D (2000) A review of sugar related disputes under the North American Free Trade Agreement. International Sugar Journal 102(1223):596-602

Kennedy P, Schmitz A (2009) Production response to increased imports: the case of U.S. sugar. Journal of Agricultural and Applied Economics 41(3):777-789 https://doi.org/10.1017/S1074070800003217

Knutson R, Westhoff P, Sherwell P (2010) Trade liberalizing impacts of NAFTA in sugar: global implications. International Food and Agribusiness Management Review 13(4):1-16

Lewis K, Schmitz T (2015) The impact of partial Mexican government sugar industry ownership on U.S. and Mexican sugar trade. Journal of Agribusiness 33(1):17-38

Madigan J (2017) Sweet innovation: healthier products and less volatile inputs will spur industry growth. IBISWorld, Industry Report 31135:1-41

Myers M, Bacon F (2004) The determinants of corporate dividend policy. Academy of Accounting and Financial Studies Journal 8(3):17-28

Rumelt RP (1991) How much does industry matter? Strategic Management Journal 12(3):167-185

Sanders M IV (2018a) Imbalanced breakfast: the wealthier, more-rushed population has demanded fewer industry products. IBISWorld, Industry Report 31123:1-38

Sanders S IV (2018b) Sticky situation: slow growth is on the horizon, but declining soda consumption will hurt demand. IBISWorld, Industry Report 31193:1-37

Schmitz T (2018) Impact of the 2014 suspension agreement on sugar between the United States and Mexico. Agricultural Economics 49(1):55-69 https://doi.org/10.1111/agec.12395

Schmitz T, Lewis K (2015) Impact of NAFTA on U.S. and Mexican sugar markets. Journal of Agricultural and Resource Economics 40(3):387-404

Schumacher S, Boland M (2005) The persistence of profitability among firms in the food economy. American Journal of Agricultural Economics 87(1):103-115 https://doi.org/10.1111/j.0002-9092.2005.00705.x

Stivaros C (2017a) Bubble up: soda producers will refresh product lines to curb falling demand. IBISWorld, Industry Report 31211:1-41

Stivaros C (2017b) Munch on: changing consumer tastes will encourage operators to create healthier products. BBISWorld, Industry Report 31182:1-39

Stivaros C (2017c) Simply delicious: operators will create new products in response to rising health concerns. IBISWorld, Industry Report 31135:1-37

Stivaros C (2017d) Snack break: healthier products and more innovative flavors will boost industry growth. IBISWorld, Industry Report 31191:1-39

Sweetener Users Association. (2018). U. S. sugar program. Retrieved July 18, 2019, from Sweetener Users Association website: https://sweetenerusers.org/U-s-sugar-program/

Trejo-Pech C, Gunderson M, Baker T, Gray A, Boehlje M (2015) Assessing cash holdings in agribusiness. International Food and Agribusiness Management Review 18(4):20

Trejo-Pech C, Weldon R, Gunderson M (2016) Earnings management through specific accruals and discretionary expenses: evidence from U.S. agribusiness firms. Canadian Journal of Agricultural Economics/Revue canadienne d'agroeconomie 64(1):89-118 https://doi.org/10.1111/cjag.12063

Trejo-Pech C, Weldon R, House L (2008) Earnings, accruals, cash flows, and EBITDA for agribusiness firms. Agricultural Finance Review 68(2):301-319 https://doi.org/10.1108/00214660880001232

Triantis, A. (2016). Economic effects of the U.S. sugar policy (No. April 2016; pp. 1-52). Retrieved from American Sugar Alliance website: https://sugaralliance.org/wp-content/uploads/2013/10/Triantis-Sugar-Policy-Study.pdf

Tukey JW (1962) The future of data analysis. The Annals of Mathematical Statistics 33(1):1-67 
USDA ERS. (2018). Sugar and sweeteners yearbook tables. Retrieved July 19, 2018, from United States Department of Agriculture. Economic Research Service website: https://www.ers.usda.gov/data-products/sugar-and-sweetenersyearbook-tables.aspx

USDA FAS. (2019). Sugar: world markets and trade (No. May 2019; pp. 1-7). Retrieved from https://apps.fas.usda.gov/ psdonline/circulars/sugar.pdf

Wernerfelt B, Montgomery CA (1988) Tobin's q and the importance of focus in firm performance. The American Economic Review 78(1):246-250

White H (1980) A heteroskedasticity-consistent covariance matrix estimator and a direct test for heteroskedasticity. Econometrica 48(4):817-838 https://doi.org/10.2307/1912934

Wojan T, Brown J, Lambert D (2014) What to do about the "cult of statistical significance"? A renewable fuel application using the Neyman-Pearson protocol. Applied Economic Perspectives and Policy 36(4):674-695 https://doi.org/10.1093/ aepp/ppu013

Wooldridge J (2002) Econometric analysis of cross section and panel data. Cambridge University Press, Cambridge Wooldridge J (2013) Introductory econometrics. Southwestern Press, United States

Zahniser, S., Kennedy, L., Nigatu, G., \& McConnell, M. (2016). A new outlook for the U.S.-Mexico sugar and sweetener market (No. SSSM-335-01; p. 53). Retrieved from Economic Research Service/USDA website: https://www.ers.usda.gov/webdocs/ publications/74632/60121_sssm-335-01.pdf?v=0

\section{Publisher's Note}

Springer Nature remains neutral with regard to jurisdictional claims in published maps and institutional affiliations.

Submit your manuscript to a SpringerOpen ${ }^{0}$ journal and benefit from:

- Convenient online submission

- Rigorous peer review

Open access: articles freely available online

High visibility within the field

Retaining the copyright to your article

Submit your next manuscript at $\boldsymbol{\sim}$ springeropen.com 